\title{
UMA VIAGEM LONGA DEMAIS, UM RETORNO DEVASTADOR
}

\author{
A TOO LONG TRAVEL: THE PORTUGUESE \\ 'RETURNING' FROM AFRICA
}

\author{
Simone Pereira Schmidt *
}

\begin{abstract}
RESUMO
Muito já se escreveu sobre o drama vivido pelos 'retornados' a Portugal, findo o período colonial nos países africanos. Entretanto, alguns romances de publicação mais recente - nomeadamente, Caderno de memórias coloniais, de Isabela Figueiredo (2009), e O retorno, de Dulce Maria Cardoso (2012) - retomam o tema pela chave da memória: subjetiva, familiar e histórica, ensejando uma reaproximação às experiências vividas pelos retornados, quarenta anos passados da independência das ex-colônias. Numa perspectiva feminista e pós-colonial, podemos identificar na leitura dos romances algumas particulares injunções de gênero e raça que subsistem ainda hoje, como rastros da memória colonial por resolver. Este artigo busca investigar esse aspecto, ao mesmo tempo em que procura identificar quem são e o que dizem os sujeitos que, colocando em xeque a ordem a colonial-patriarcal, acabam por se situar à margem da mesma, o que lhes permite, na forma do relato de memória ou de pós-memória, contruir uma contranarrativa da memória colonial.
\end{abstract}

PALAVRAS-CHAVE: retorno, memória, pós-colonial.

\section{ABSTRACT}

Much has been written about the traumatic experience of the 'returned' to Portugal, after the colonial period in African countries. However, some recently publicated novels - notably, Caderno de memórias coloniais (Isabela Figueiredo, 2009), and O retorno (Dulce Maria Cardoso, 2012) - retake this subject through a subjective discourse, focusing family memories, forty years after the independence of former colonies. In a postcolonial feminist perspective, we can identify in these novels some particular gender 
and race injunctions that exist today, such as traces of a unresolved colonial memory. This article intends to investigate who are the subjects of these memory discourses that put into question the colonial-patriarchal order, situated on the margins, which enable them to build a conter-narrative of colonial memory.

KEYWORDS: Portuguese return; memory; postcolonial.

Quando, em 1975, declararam-se oficialmente independentes os países africanos que, após mais de uma década de lutas, enfim se libertavam do poder colonial exercido pelo Estado português, um novo momento se inaugurava para todos. E, como não poderia deixar de ser, se para as nações recém- independentes, como Angola e Moçambique, este novo momento trazia profundas transformações que transbordavam do social e político para todas as esferas da vida, o mesmo veio a acontecer, em grau talvez menos intenso mas igualmente significativo, com a antiga metrópole. Com a independência de suas ex-colônias, Portugal encarava o fim do seu imperialismo tardio, mantido pela força ditatorial de Salazar e visivelmente desgastado, tendo em seu último período sobrevivido às custas de um imaginário imperialista que muito custou à população ${ }^{1}$. A bem da verdade, desde muito antes, o império português era já marcado por este forte componente imaginário. Como Eduardo Lourenço analisou exemplarmente em O labirinto da saudade, "Poucos países fabricaram acerca de si mesmos uma imagem tão idílica como Portugal. $\mathrm{O}$ anterior regime atingiu nesse domínio cumes inacessíveis, mas a herança é mais antiga e o seu eco perdura (LOURENÇO, 1982, p. 79)².

O declínio desse 'império’ se tornou incontestável principalmente a partir do novo momento histórico que no cenário internacional se inaugurara no pós-guerra, com o fim do colonialismo exercido pelos países europeus na África e na Ásia, e internamente, com o gradativo ocaso do salazarismo, culminando com a decadência física e a morte do ditador, e o fracasso político de seus seguidores.

Um exemplo emblemático do grande impacto vivido por Portugal nesse período de mudanças encontramos na conhecida figura dos retornados - os portugueses que tiveram de migrar às pressas com o fim das guerras de libertação e a consequente independência das ex-colônias, após décadas de permanência em solo africano, empreendendo assim um 'retorno' à pátria que, de fato, não (ou não mais) lhes pertencia. Violentando sua identidade adaptada à vida na África, os retornados empreenderão uma espécie muito particular de viagem: a contragosto, precipitada por forças históricas que não aceitam e não compreendem, e em condições extremamente precárias. Não se sentem acolhidos pelo país ao qual retor- 
nam, como também não se sentiam inteiramente pertencentes aos países africanos em que viviam. Não sendo eles nem de um, nem de outro lugar, sua viagem de retorno assinala sua condição in between, tal como, em outro contexto, Homi Bhabha (1998, p. 19-42) configurou a identidade diaspórica dos sujeitos pós-coloniais.

Quarenta anos se passaram desde a independência das ex-colônias de Portugal em território africano. Quarenta anos desde o fim das guerras de libertação, o fim do sonho de um império e o retorno dos portugueses. Muito já se disse sobre o retorno ${ }^{3}$, mas recentemente presenciamos um forte movimento de revisitação ao tema, seja numa perspectiva ainda marcada por certa nostalgia da 'África perdida' como assinala Margarida Calafate Ribeiro (2012, p. 92) , sobre autores como Ricardo Saavedra (Os dias do fim, 1995; 2008) e Carlos Vale Ferraz (Fala-me de África, 2007)4, seja num tom provocativamente crítico e demolidor acerca do sonho imperial, como vemos na escrita de uma geração de 'filhos (ou filhas) do retorno, de que as narrativas de Isabela Figueiredo (Caderno de memórias coloniais, 2009) $)^{5}$ e Dulce Maria Cardoso (O retorno, 2012) são exemplares ${ }^{6}$.

Coube à geração dos filhos daqueles que recolheram às pressas os seus pertences e cruzaram o mar de volta à metrópole recontar essa história em tom mais pessoal, subjetivo. Revisitar um capítulo tão doloroso da memória familiar foi uma espécie de desafio que os filhos e filhas do retorno assumiram como tarefa sua. Tinham eles pouco mais, pouco menos de dez anos, saíam da infância, e viveram com seus pais e irmãos a profunda transformação de suas vidas, ao mudar de casa, de país e continente, vindos dos países africanos onde haviam passado seus primeiros anos de formação. "Tinha 11 anos. Fui a minha primeira personagem. Achei sempre: vou contar isto, vou contar isto" (apud GOMES, 2015). As palavras de Dulce Maria Cardoso traduzem seu trabalho de recriação da memória, através da ficção, para executar aquilo que Isabela Figueiredo considera um "modo de sobrevivência": "Tudo em mim cumpre a função da sobrevivência. É uma escolha dura, com custos emocionais elevados, contudo nunca me pareceu ser possível viver de outra forma" (FIGUEIREDO, 2011c).

Emociono-me especialmente com essa geração de filhos que buscam, pela via da memória, recontar a experiência protagonizada por seus pais, para através desse exercício reencontrá-los, compreendê-los, e talvez perdoá-los. Emociono-me porque pertenço a uma geração que no Brasil dos anos 70 atravessava penosamente o umbral que nos expulsava da infância, e se lá, do outro lado do oceano, eles cumpriam sua passagem na amargura de um exílio forçado, por aqui amargávamos outros traumas, atravessados por sombras e silêncio.

Este tomar para si a tarefa de juntar os cacos de uma memória familiar que de outro modo se perderia, ainda que pela chave da reinvenção (pois a memória, como lembra Isabela Figueiredo, adapta-se, trabalha-se, reescreve-se) (FIGUEIREDO, 2011b), é trabalho realizado, de forma espe- 
cialmente aguda, veemente, cortante, pela escrita de duas mulheres dessa geração. Isabela Figueiredo e Dulce Maria Cardoso, em seus romances Caderno de memórias coloniais (2009), e O retorno(2012), nos trazem de volta ao tema do retorno, abordando-o, segundo a crítica, como 'um soco no estômago", como "uma pedrada no charco ${ }^{8 "}$.

É também pela chave da memória familiar que a cineasta Margarida Cardoso, em Natal 71, documentário realizado em 1999, revive os traumas forçadamente silenciados de uma puberdade forjada em meio à guerra colonial. Sobre a marca de um protagonismo autoral feminino incontestável nessa produção recente sobre o tema, é Margarida Cardoso quem nos traz algumas observações interessantes. Segundo a cineasta, o olhar feminino sobre essa experiência histórica acaba por ser um olhar dos "efeitos colaterais" do vivido, uma vez que atravessa a experiência não pelo meio da cena, mas por um olhar descentrado e poderíamos dizer em ricochete, porque visto pelo filtro da percepção de mulheres e crianças, "o lado mais fraco dessa história"9.

Ao falar da fragilidade que percebe em seus protagonistas, Margarida Cardoso é confrontada por seu entrevistador que discorda da suposta 'fraqueza' das mulheres, ao que ela responde que os mais fracos são o s menos protegidos, os mais invisibilizados, aqueles sobre quem recaíram as violências sem nome, invisíveis como suas vítimas. O olhar feminino sobre o retorno, portanto, trata daquilo que ficou mais escondido, as emoções e sentimentos profundos, aquilo que percorria a intimidade da casa, no momento mesmo em que ela agonizava. De narrar essas lembranças as mais pequenas e ocultas, encarregaram-se as 'filhas do retorno'. Como uma memória que precisa ser trazida à tona. Como o disco Natal $71^{10}$ que Margarida Cardoso foi buscar nos guardados de seu pai. Dessa memória de que nos fala Dulce Maria Cardoso: "Achei que era um tema que não tinha interesse nenhum, já que ninguém tratava dele (GOMES, 2015)."

Nos textos das duas autoras, são exatamente os filhos que exercerão a voz narrativa. Em Caderno de memórias coloniais, protagonista e narradora ora se misturam, ora se distanciam da figura da autora, realizando um jogo de deslizamentos para dentro e fora do gênero autobiográfico. $\mathrm{Na}$ narração em primeira pessoa, encontramos uma voz que procura desvendar, por detrás da percepção da menina que viveu os episódios relatados, aquilo que somente a compreensão adulta pode, par derrière, tornar visível. É assim que a suposta ingenuidade infantil se põe, na narrativa, à prova, quando relata a vida dos portugueses em Angola, a brutalidade das relações desiguais entre brancos e negros, as ambiguidades de sua relação com o pai, amado e odiado na mesma medida:

Quem, numa manhã qualquer, olhou sem filtro, sem defesa ou ataque, os olhos dos negros, enquanto furavam as paredes cruas dos prédios dos brancos, não esquece esse silêncio, esse frio fervente de ódio e miséria suja, dependência e submissão, sobrevivência e conspurcação.

Não havia olhos inocentes. (FIGUEIREDO, 2011, p. 27-28) 
Se em Cadernos de memórias coloniais encontramos a voz de uma narradora adulta, que empreende um doloroso acerto de contas com o passado através de seu relato, em $O$ retorno, o pacto narrativo é outro, já que neste romance o narrador é o menino Rui, que conta a história enquanto ele e sua família estão vivenciando os episódios de sua saída apressada e dramática de Angola com o fim do colonialismo, e seu regresso a Portugal.

Nos dois romances, reencontramos um topos recorrente, e muito estudado, na literatura portuguesa: a casa. Lá está ela ainda uma vez - a casa portuguesa de que tanto se falou na literatura desde o advento da burguesia, com seus mesmos traços definidores mais gerais: os personagens centrais (pai, mãe, filhos), o poder do pai, o casamento como sustentação, a moral cristã, a norma patriarcal. A casa cujas paredes foram (e ainda estão) pouco a pouco se rompendo constituiu, tradicionalmente, como sabemos, um espaço feminino. Segundo a lógica predominante em todos os espaços da sociedade patriarcal, a dimensão íntima e privada da existência, a vida doméstica que acontecia entre quatro paredes, foi historicamente considerada a menos importante, a parte menos nobre da vida, aquela que se revestia de considerável invisibilidade, e que tinha seus significados interpretados a partir de um olhar de fora para dentro; raramente o contrário. Em tempos recentes, o rompimento com essa divisão tradicional entre público/ privado trouxe a consequência de fazer valer para o mundo público aquilo que não tinha valor algum para a ordem pública, política, econômica, jurídica. Abriu-se portanto uma fenda nessa ordem, e dela emergiram novos sujeitos que passam a expressar sua memória do vivido, sujeitos que até bem pouco tempo não tinham sua própria voz, tais como as mulheres, as crianças, personagens até então secundárias na ordem dos acontecimentos.

Esta casa portuguesa, entretanto, tal como o anjo na metáfora benjaminiana ${ }^{11}$, recebe, de olhos arregalados, o impacto do vento forte da História. E o vento sopra ferozmente sobre ela, abalando seus alicerces. Forçada pela violência dos episódios que enfrenta, esta casa junta seus cacos em malas preparadas às pressas e efetua uma viagem em direção ao passado que não é mais, ou nunca foi, o seu. O Portugal que a recebe não a acolhe e não a deseja. A metáfora da casa portuguesa que viaja traduz, no contexto dos retornos, os seus múltiplos significados: as permanências (aquilo que com ela viaja), os rompimentos dolorosos, as perdas traumáticas e as mudanças necessárias.

A casa portuguesa viaja, e com ela viajam seus ritos e crenças, as prescrições da norma patriarcal, as regras de como ser homem e mulher, as desigualdades raciais sobre as quais se assentaram as vidas dos portugueses na Angola colonial, enfim, viajam a família e seus "brandos costumes". O discurso da norma patriarcal se espalha ao longo da narrativa de $O$ retorno, em frases aparentemente despretensiosas como: "O pai nunca deixa que a mãe diga que sou bonito, os homens não se querem bonitos" (CARDOSO, 2012, p 39); "Um homem não chora” (p 40); "Um homem só vomita quando fica bêbado" (p. 17); "O pai piscava-me o olho e defendia-me...Eu e o pai 
pertencemos ao mesmo clube" ( p 27), “Tinha tanta vontade de coçar-me, mas coçar é coisa de raparigas, os homens têm de estar preparados para tudo" ( p. 42).

É dentro deste rígido sistema patriarcal que se situam, na formação do menino Rui, protagonista e narrador de $O$ retorno, as regras para se fazer homem, em contraposição ao mundo das meninas e das mulheres: "Uma rapariga tem de ter ainda mais cuidado do que um rapaz, tem de se comportar de outra maneira, se uma rapariga fica falada ninguém a quer" (CARDOSO, 2012, p. 60).

Em Caderno de memórias coloniais, as questões de gênero se escancaram de forma ainda mais crua, desde o início da narrativa, e desde sempre imbricadas às tensões raciais:

As pretas tinham a cona larga e essa era a explicação para parirem como pariam, de borco, todas viradas para o chão, onde quer que fosse, como os animais. A cona era larga. A das brancas não, era estreita, porque as brancas não eram umas cadelas fáceis, porque à cona sagrada das brancas só lá tinha chegado o do marido, e pouco, e com dificuldade, que elas eram muito estreitas, portanto muito sérias, e convinha que umas soubessem isto das outras. Limitavam-se ao cumprimento das suas obrigações matrimoniais, sempre com sacrifício, pelo que a fornicação era dolorosa, e evitável, por isso é que os brancos iam à cona das pretas. As pretas não eram sérias, as pretas tinham a cona larga, as pretas gemiam alto, porque as cadelas gostavam daquilo. Não valiam nada. (FIGUEIREDO, 2011, p. 13).

Interessante agregar a essa citação os comentários sobre o romance de Anita Martins de Moraes, que com agudeza observa:

Notemos que o assunto das mulheres brancas é o corpo das mulheres negras. Ou melhor: o corpo reduzido a sexo da mulher negra que se contrapõe ao corpo de sexo reduzido da mulher branca. Na fala da branca, a negra é semelhante ao animal: "Que diferença havia entre uma negra e uma coelha?" (p. 14) A repressão sexual fica indicada, resultando na super-desvalorização da mulher negra, que será suporte para o que a branca nega em si, com efeitos de ampliação e deformação. Ou seja, a sexualidade que a branca nega em si se projeta, desfigurada, no corpo da mulher negra, desumanizando-a. O Caderno de memórias coloniais capta, assim, de maneira aguda, a brutalidade e perversidade desta sociedade extremamente racializada (MORAES, 2011).

Assim como nas tensões vividas no tempo colonial, após o retorno a Portugal as questões de gênero seguem revelando sua face sempre violenta, que a autora não deixa passar em branco, mesmo quando essa violência se traveste de fato banal e cotidiano:

Era novembro e eu tinha acabado de chegar.

Nas Caldas da Rainha, em 1975, para ir para a escola atravessava uma rua negra, com alcatrão levantado nas bordas, sem 
passeio: um túnel de edifícios muito sujos pelo tempo, dos dois lados da via. Era uma rua cinzenta-escura do princípio ao fim.

[...] Quando passava frente ao portão, três homens atarracados, com mãos e roupa sujas do trabalho, gritavam-me comentários sexuais que me esforçava por não ouvir. Colava o pescoço aos ombros, comprimia as paredes dos ouvidos, fechava os olhos, fechava-me, e mesmo sem querer escutava mamas, cona, rabo, palavras que vinham adornadas com advérbios ou verbos de péssima expressão. Insultos.

Tinha 12 anos, quase 13, e insultavam-me por evidenciar mamas, cona e rabo, não percebendo eu o desmerecimento. Insultavam-me por já ser uma mulher. Isso bastava. (FIGUEIREDO, 2011, p. 121).

Com mal contida indignação contra a violência que abatia o corpo da menina recém chegada à metrópole, a narradora adulta arremata a cena rememorada com um comentário mordaz sobre o conservadorismo daquela sociedade: "Não sei se a rua negra ainda existe. Em Portugal tudo demora muito tempo a mudar." (FIGUEIREDO, 2011, p. 122).

Nas lições que recebem os meninos e as meninas dessas histórias destaca-se, lado a lado com as regras que os ensinam a se tornarem homens e mulheres, um maciço ensinamento sobre a desigualdade entre brancos e negros, cimento sobre o qual se constroem todas as relações coloniais. Dessa forma, como indica Mário Lugarinho ao investigar as intrincadas relações entre masculinidade e colonialismo,

[...] a superioridade do homem por sobre a mulher e do homem branco europeu por sobre todos os homens não brancos e não europeus ficou garantida, instituindo as exceções a partir de um conjunto de oposições: aqueles que não se colocavam em função do padrão masculino, europeu e branco, eram tratados sob o estatuto da subordinação, infantilizados, feminilizados e/ou marginalizados"(LUGARINHO, 2013, p 20).

Lições dessa natureza povoam as páginas dos dois romances. Em O retorno, Dulce Maria Cardoso evidencia o fardo com que sua geração teve de lidar, desvencilhando-se a duras penas de um imaginário marcado por sentenças como:

O problema é que eles não têm cabeça, eles são os pretos, os que conhecemos e os que não conhecemos. Os pretos. A não ser que se queira explicar o que são, aí é o preto, o preto é preguiçoso, gostam de estar ao sol como os lagartos, o preto é arrogante, se caminham de cabeça baixa é só para não olharem para nós, o preto é burro, não entendem o que se lhes diz, o preto é abusador, se lhes damos a mão querem logo o braço, o preto é ingrato, por muito que lhes façamos nunca estão contentes, podia-se estar horas a falar do preto mas os brancos não gostavam de perder tempo com isso, bastava dizer, é preto e já se sabe do que a casa gasta. (CARDOSO, 2012, p. 25). 
E em Caderno de memórias coloniais, encontramos um tom semelhante, de perspectiva crítica, sobre as desigualdades raciais vividas nas antigas colônias.

Em Moçambique era fácil um branco sentir prazer de viver. Quase todos éramos patrões, e os que não eram, ambicionavam sê-lo.

Havia sempre muitos pretos, todos à partida preguiçosos, burros e incapazes a pedir trabalho, a fazer o que lhes ordenássemos sem levantar os olhos. De um preto dedicado, fiel, que tirasse o boné e dobrasse a espinha à nossa passagem, a quem se pudesse confiar a casa e as crianças, deixar sozinho com os nossos haveres, dizia-se que era um bom mainato. (FIGUEIREDO, 2011, p. 25)

Ao racismo como prática incorporada, encarada como coisa natural e por isso não passível de qualquer crítica ou censura, agregava-se o lugar central ocupado pela sexualidade na moral colonial. Falar do colonialismo português - e de certo modo, da colonialidade que dessa experiência histórica decorre - é falar, antes de tudo, da centralidade do sexo. Segundo o ethos do colonizador português, produzir a civilização se igualava, em muitos sentidos, a "fazer sexo" (PINHO, 2004, p. 101). Mas o sujeito desta sexualidade era sempre o homem branco, espécie de "civilizador erótico" (PINHO, 2004, p. 102). É dentro desse conjunto de regras morais, que encontramos algumas cenas nos romances que podem ser considerados exemplares de uma prática sexual, racista e patriarcal, a qual foi definida por Sueli Carneiro (2001, p. 1) como o "estupro colonial". E de que outra forma seriam definidos discursos como estes?

Que diferença havia entre uma negra e uma coelha? Que branco perfilhava filhos a uma negra? (FIGUEIREDO, 2011, p. 14)

[...] passávamos horas a falar de como seria fazer ginga ginga com raparigas brancas, sabíamos que não era a mesma coisa do que fazer com as pretas que nem cuecas usam e fazem aquilo com qualquer um e se quisermos até fazem com dois ou três de seguida (CARDOSO, 2012, p. 43)

Que preta é que queria levar porrada? Quantos mulatos conheciam o pai? [...] uma negra não tinha poder para reclamar paternidade. Ninguém lhe daria crédito. (FIGUEIREDO, 2011, p. 14)

Entretanto, se a casa portuguesa viaja de um continente ao outro carregando consigo, como vimos, o fardo de sua tradição patriarcal e racista, há, por outro lado, muita coisa que se deixa pelo caminho, muita coisa que se perde. Muita perda, literalmente. Em seu blog Novo Mundo, Isabela Figueiredo explicita esse fato, ao falar de sua ficção: "O Caderno, quase na $5^{\text {a }}$ edição, [...] é, para mim, um texto sobre perda, múltiplas perdas” (FIGUEIREDO, 2011 a).

Exilados de seu mundo para sempre acabado, os personagens de $O$ retorno oscilam entre duas frases que definem seu movimento contrapontístico, que nos lembra a compreensão formulada por Edward Said 
acerca da experiência do exílio ${ }^{12}$. Contraponto entre a casa como lugar perdido ("não há lugar como a nossa casa", suspira a mãe muitas vezes, enquanto vivem intermináveis meses alojados num hotel do Estoril, junto com outras centenas de retornados) e a casa como lugar que tem de ser forçosamente reinventado ("Um quarto pode ser uma casa e este quarto e esta varanda de onde se vê o mar é a nossa casa” (CARDOSO, 2012, p.163), diz Rui para si mesmo, ousando incorporar o incerto e provisório como parte de sua nova vida, em direção contrária ao saudosismo melancólico de seus pais sobre a casa, a África e a vida deixadas para trás. Como afirma Ana Filipa Prata em artigo sobre o cronótopo do hotel e seu significado na formação da memória em $O$ retorno,

O hotel, que constitui uma plataforma de trânsito prolongado, em alguns casos por vários anos, da ponte aérea Lisboa-Luanda é, no relato de Rui, o lugar onde se materializa a descoberta da imprevisibilidade da vida, bem como o reconhecimento da instabilidade identitária, assente numa dimensão precária da linguagem (PRATA, 2014, p. 71).

Talvez uma das passagens mais marcantes e definidoras do sentimento de exílio encontremos em Caderno de memórias coloniais, quando, já regressada à metrópole, a protagonista encontra um dia, por acaso, um jovem marinheiro moçambicano, e seu desejo de puxar conversa, contar ao jovem que ela também nasceu em Moçambique, leva-a algumas de suas mais profundas reflexões sobre o retorno e sua condição de exilada:

Os desterrados, como eu, são pessoas que não puderam regressar ao local onde nasceram, que com ele cortaram os vínculos legais, não os afectivos. São indesejados nas terras onde nasceram, porque a sua presença traz más recordações.

$\mathrm{Na}$ terra onde nasci seria sempre a filha do colono. Haveria sobre mim essa mácula. A mais que provável retaliação. Mas a terra onde nasci existe em mim como uma mácula impossível de apagar. Persigo oficiais marinheiros que trazem escrita, na manga do casaco, a palavra Moçambique! (FIGUEIREDO, 2011, p. 133)

Quando partiu sozinha de Moçambique para a metrópole, no conturbado apagar das luzes coloniais, a menina Isabela havia embarcado com a missão que lhe atribuíram seus pais: contar aos da metrópole os horrores da guerra, e todo o mal então praticado pelos africanos contra os portugueses:

[...] contas tudo o que nos têm feito, diz que perdemos tudo, que o dinheiro não vale nada, que não há que comer, que mataram os Monteiros, que a filha do Sousa mais o marido estão presos, conta que estamos quase a ir. Diz que eles hão de matar-se uns aos outros. Que não querem trabalhar e morrerão de fome. Que África sem brancos está condenada. Vão chorar e clamar tanto por nós! (FIGUEIREDO, 2011, p. 107) 
Na hora do embarque, sob o peso da solidão daquele forte momento, de partida, despedida, de fim de uma vida e de toda uma era, a menina vive um intenso e fulgurante rito de passagem, que faria dela uma mulher. E na passagem da menina à mulher, cumpre-se um ritual ainda mais profundo, aquele que a distanciaria para sempre dos seus: Isabela retornada não será fiel à palavra de seus pais:

Quando o avião tomou altura houve dentro da cabina um silêncio fundo sobre a baía de Lourenço Marques, os subúrbios, as palhotas, as terras de cultivo, o mato que vi enquanto subíamos.

Em silêncio, mas num silêncio ainda mais fundo, porque afinal já era uma mulher, voltei a chorar o que perdia e haveria de pagar. A dívida alheia que me caberia.

Nunca entreguei a mensagem de que fui portadora. (FIGUEIREDO, 2011, p. 111).

E é assim, sentindo-se traidora em relação aos sentimentos e expectativas de seus pais, que a narradora perceberá sua necessidade de escrever, como forma de curar (?) a dor de sua condição de exilada, e de expiar, ainda que parcialmente, a culpa que carrega consigo, culpa que resulta do abismo que se cavou entre sua experiência e a de seus pais; culpa que resulta ainda, num plano mais amplo, de toda a experiência colonial portuguesa na África:

[...] Moçambique é essa imagem parada da menina ao sol, com as tranças louras impecavelmente penteadas, perante essa criança negra empoeirada, quase nua, esfomeada, num silêncio em que nenhum sabe o que dizer, mirando-se do mesmo lado e dos lados opostosda justiça, do bem e do mal, da sobrevivência.

Um desterrado como eu é também uma estátua de culpa. E a culpa, a culpa, a culpa que deixamos crescer e enrolar-se por dentro de nós como uma trepadeira incolor, ata-nos ao silêncio, à solidão, ao insolúvel desterro. (FIGUEIREDO, 2011, p. 134)

O abismo que a narradora do Caderno de memórias coloniais percebe entre a sua experiência e a de seus pais, quem sabe doesse menos se ela pudesse vislumbrar a dimensão coletiva dessa distância entre as gerações. Pois essa distância entre o que viveram os pais e o que relataram os filhos dos retornados se mostra com certa recorrência nas narrativas do retorno. No romance de Dulce Maria Cardoso, enquanto os pais lamentam e vivenciam o exílio como a fratura incurável que marca o exilado, como aponta Said (2003), o protagonista Rui vivencia também o exílio, mas de outra maneira. Essa perda do lar, se por um lado é marcada pela angústia das incertezas ao abandonarem referenciais seguros em termos de crenças e pertencimentos, por outro, aponta para a possibilidade de reinvenção de seus significados emocionais, afetivos e históricos. O relato assim confirma, de certo modo, o caráter contrapontísitico da experiência do exílio, 
definida por Said não somente como fratura e ferida, mas também como chave de reinvenção dos sujeitos. O exílio, segundo Said, acena com suas fugidias promessas: ele é "a vida levada fora da ordem habitual [...] nômade, descentrada, contrapontística", e "assim que nos acostumamos a ela, sua força desestabilizadora entra em erupção novamente” (SAID, 2003, p. 60).

Ao discutir o caráter ambíguo do exílio vivido pela protagonista-narradora de Caderno de memórias coloniais, Ana Luísa Amaral compara a sua condição de exilada com a identidade nômade definida pela teórica Rosi Braidotti:

Penso na teórica feminista Rosi Braidotti e na sua re-interpretação do exilado enquanto nómada. No sujeito nómada, o que está em causa não é a desterritorialização, ou o deslocamento per se, mas a liberdade discursiva em relação às narrativas dominantes, porque é um sujeito em devir, que se vai tornando - e eu saliento aqui a pulverização e a recusa de identidades estáveis. Recusa imposta, dir-me-á a autora. Liberdade que não é escolha, acrescentará. (AMARAL, 2010)

Podemos assim compreender o contraponto como marca definidora e inapagável da experiência dos retornados. Se para a geração dos pais que protagonizaram o retorno este foi vivido exclusivamente como perda traumática, coube à geração dos filhos e filhas ultrapassar o silêncio que se cola ao corpo dos traumatizados, furar esse silêncio, dar testemunho do que viveram seus pais, os quais se recusaram a falar sobre sua experiência. Deste silêncio, cúmplice de um suposto esquecimento, tão impotente quanto nefasto, nos falam as duas autoras em seus romances. Diz a narradora de Caderno de memórias coloniais: "A prisão do meu pai foi tabu na família. Ele nunca nos falou sobre o que se passou lá dentro, e nós tivemos pudor em perguntar, pelo que imagino o pior. A sombra do que não se sabe é sempre enorme" (FIGUEIREDO, 2011, p. 125). E assim nos conta o narrador de $O$ retorno:

De vez em quando parecia que o pai ia começar a falar mas nunca disse nada. [...] Não falamos do que aconteceu ao pai mas é como se isso sugasse todas as conversas. Todas as conversas e todos os silêncios. O Lee andava sempre a ler nas revistas coisas sobre os buracos negros, buracos que são como estrelas ao contrário e que em vez de darem luz engolem tudo o que está à sua volta, até a própria luz. A prisão do pai faz a mesma coisa (CARDOSO, 2012, p. 252-253).

Se o silêncio encobriu toda a experiência vivida pela geração dos retornados, é neste intervalo entre o silêncio e a fala, entre o trauma e o testemunho, que se separam os pais e os filhos/filhas que juntos viveram esse momento histórico. Pois através de sua ficção, os filhos/filhas tomam para si a tarefa de dar testemunho, ainda que sob o estigma de se tornarem os traidores de suas próprias famílias, ferindo seu luto de uma África perdida, transformando-a em palavras, e palavras não de saudade, mas de denúncia, como revela a narradora do Caderno de memórias coloniais: 
Foi quando, devagar, comecei a tornar-me a pior inimiga do meu pai. A inimiga lá dentro, calada. Que vê, e escuta e nem pediu autorização. Foi quando comecei a tornar-me a toupeira.

Só muitos anos mais tarde, muitos, muitos, compreendi que saber ler, o acesso a essa chave para descodificação do segredo, me transformara, contra todas as vontades, na toupeira que lhes havia de roer todas as raízes, devagar, uma de cada vez, até restar pó.

O meu pai tinha a camisa branca e eu, o seu tesouro, a sua vida, sujei-lha de terra para sempre. (FIGUEIREDO, 2011, p. 61-62)

Lançando mão do conceito de pós-memória ${ }^{13}$ para analisar a escrita construída pela geração de escritores que, tal como Isabela Figueiredo, elaboram um testemunho "adotivo" da experiência do retorno, "construído a partir de memórias de infância”, Margarida Calafate Ribeiro destaca o caráter conflituoso de sua narrativa, dividido entre o privado e o público, o dever de amor familiar e a responsabilidade ética do testemunho:

E aqui reside a cisão, manifesta na impossibilidade de amor, pela traição, que o livro de Isabela Figueiredo a tanto custo grita e que, no limite, o torna trágico. Aquele pai de quem ela dificilmente se despegou no aeroporto de Lourenço Marques, estava, como Lourenço Marques e sua infância, perdido para sempre [...] (RIBEIRO, 2012, p. 95)

Em síntese, o testemunho que transita entre a memória familiar e um olhar sobre o retorno como trauma coletivo, decorrente da experiência colonial, acaba por não poupar os portugueses de sua responsabilidade histórica:

Ouvi isto toda a minha vida. Venham falar-me no colonialismo suavezinho dos portugueses... Venham-me com essa história da carochinha.As pessoas não mudam. Um branco que viveu o colonialismo será um branco que viveu o colonialismo até ao dia da morte. E toda a minha verdade é para eles uma traição. Estas palavras, uma traição. Uma afronta à memória do meu pai, mas com a memória do meu pai podemos bem os dois. (FIGUEIREDO, 2011, p. 131).

Em O retorno, o conflito entre a geração de pais e filhos é menos evidente, mas as transformações vividas pelo protagonista-narrador sugerem que ele, ao fim da narrativa, se mostra consciente de ter-se completado um ciclo, e de ter-se cumprido uma passagem. A narrativa que tinha iniciado no último dia de sua família em solo angolano, se encerra no último dia passado no hotel dos retornados, dia em que vão se mudar para uma casa modesta onde reiniciarão a vida. Entre um dia e outro, início e fim da narrativa, toda uma iniciação se cumpriu para o personagem. Viveu na pele a angústia das necessidades mais básicas, foi tratado na metrópole como o "outro selvagem" pelos portugueses, foi enfim forçado a confrontar-se com o imperativo de se tornar um homem para além das normas patriarcais em que foi criado. 
Dessas profundas transformações de ordem subjetiva, provocadas pelas experiências vividas em torno da ruína do projeto colonial, nos dá testemunho a geração dos filhos dos retornados. E de forma tão intensa misturam a experiência histórica, a vivência subjetiva e familiar e sua reinvenção ficcional que se tornou comum ouvir desses e dessas autoras a confissão de um certo sentimento de culpa por se sentirem traindo a memória silenciosa de seus pais, tal como se evidencia nos depoimentos de Isabela Figueiredo.

Contudo, mais forte do que culpas e acertos de contas em família, certamente o que fica para nós, leitores, é podermos perscrutar de forma mais sensível, mais íntima, o que ficou por dizer nos cantos escuros da casa portuguesa, que, forçada e a contragosto, moveu-se. E nossa escuta desse silêncio enfim rompido se deve à voz dos filhos, ou melhor, das filhas dos retornados. É o que podemos compreender ao ouvir as seguintes palavras de Isabela Figueiredo sobre seu romance: "Perdoem esta falta de modéstia congénita, que cai sempre tão mal, mas jurei não dizer o que não penso: ganhei a notoriedade de uma voz. Tornei-me uma voz" (FIGUEIREDO, 2010), o que revela, acima de tudo, que o rito de passagem vivido pelos personagens de um e outro romance, pari passu com as dores e transformações da experiência do retorno, acaba por configurar um processo profundamente empoderador, de transformação do silêncio cúmplice em voz que transcende a esfera da vida privada e invade a cena pública, constituindo um relato-testemunho, um discurso de denúncia, e um sujeito que os enuncia.

$\mathrm{Na}$ conclusão deste artigo, é a voz desses narradores que ecoam e dominam. Revendo toda a experiência vivida no hotel do Estoril, no dia em que dali estão partindo, o personagem Rui está sozinho no terraço e olha para o céu (e não mais para o mar). O mar ficou além, no passado, no mesmo lugar onde ficou a infância e a África perdidas ("A que casa regressarás? Quanto tempo permanecerás sobre a cova onde o teu passado apodrece?", pergunta-se a narradora ao concluir os seus Cadernos) (FIGUEIREDO, 2011, p. 136). O mar agora distante, o céu por sobre sua cabeça, Rui parece se despedir do passado, e começa a empreender uma outra viagem: para dentro desta terra, que o acolhe mal e onde será sempre um retornado ("Em Portugal habituei-me cedo a ser alvo de troça ou de ridículo, por ser retornada ou por me vestir de vermelho ou lilás", diz Isabela nos Cadernos) (FIGUEIREDO, 2011, p. 119), mas que, ainda assim, é a terra possível, o único caminho, a realidade.

Na cena do terraço, Rui vê cruzar um avião e lhe passa pela mente a ideia de escrever algumas palavras no chão, ali mesmo. Sua decisão é incerta como incertos se tornaram todos os momentos, agora que sua iniciação se cumpriu e o provisório e o precário entraram de vez em sua vida. Talvez escreva, talvez não. E se escrever, os que sobrevoarem o hotel verão lá do alto, inscritas no chão, as palavras que resumem sua sofrida, definitiva e transformadora experiência: "Eu estive aqui”. (CARDOSO, 2012, p. 267), 
como a testemunhar o que viveram todos aqueles, como ele, filhos de retornados, experiência indelevelmente marcada em cada um. "O meu corpo foi uma guerra, era uma guerra, comprou todas as guerras" (FIGUEIREDO, 2011, p.127), Isabela disse. E sabia do que falava.

\section{REFERÊNCIAS BIBLIOGRÁFICAS}

AMARAL, Ana Luísa. "Caderno de memórias coloniais". Texto postado em 18.mar.2010. Disponível em https://angnovus.wordpress. com/2010/03/18/ana-luisa-amaral-sobre-o-\%C2\%ABcaderno-de-memorias-coloniais\%C2\%BB/. Acesso em 14.fev.2016.

BENJAMIN, Walter. “Teses sobre o conceito de História”. In: Obras escolhidas. vol. 1. Magia e técnica, arte e política. Ensaios sobre literatura e história da cultura. São Paulo: Brasiliense, 1987. p. 222-232.

BHABHA, Homi K. O local da cultura. Belo Horizonte, Editora UFMG, 1998.

CARDOSO, Dulce Maria. O retorno. Rio de Janeiro: Tinta da China, 2012.

CARDOSO, Margarida. Natal 71. Documentário. Portugal, 1999.

_. Natal 71.[resenha]. Disponível em http://www.cinept.ubi.pt/pt/ filme/2074/Natal+71. Último acesso em 14.fev.2016.

. Natal 71 [excerto]. Publicado em 8 mar 2012. Disponível em https://www.youtube.com/watch?v=4WAkD9GL2nQ. Último acesso em 14.fev.2016.

CARNEIRO, Sueli. "Enegrecer o feminismo: a situação da mulher negra na América Latina a partir de uma perspectiva de gênero". Artigo apresentado no Seminário Internacional sobre Racismo, Xenofobia e Gênero, Durban, África do Sul, ago 2001. Publicado em espanhol na revista LOLA Press n. 16, nov.2001. Disponível em: http://arquivo.geledes.org.br/ em-debate/sueli-carneiro/17473-sueli-carneiro-enegrecer-o-feminismo-a-situacao-da-mulher-negra-na-america-latina-a-partir-de-uma-perspectiva-de-genero

FIGUEIREDO, Isabela. Caderno de memórias coloniais. 5.ed. Coimbra: Angelus Novus, 2011.

. “Parabéns, querido Caderno". Postagem em 18.nov.2010. Disponível em http://novomundoperfeito.blogspot.com.br/2010/11/parabens-querido-caderno.html. Último acesso em 14.fev.2016.

(a). “A minha África é uma história que cada um de nós carrega em silêncio”. Postagem em 7.mar.2011. Disponível em http://novomundoperfeito.blogspot.com.br/2011_03_01_archive.html. Acesso em 14.fev.2016. 
(b) "Das castas entre os retornados". Postagem em 9.ago.2011. Disponível em http://novomundoperfeito.blogspot.com.br/2011_08_01_ archive.html. Acesso em 14.fev.2016.

(c) "Modo de sobrevivência". Postagem em 2.out.2011. Disponível em http://novomundoperfeito.blogspot.com.br/search/label/Caderno\%20 de\%20Mem\%C3\%B3rias\%20Coloniais. Acesso em 14.fev.2016.

GOMES, Kathleen. "Há retornados que acham que sou uma traidora”. Entrevista a Dulce Maria Cardoso. Público, 17 set. 2015. Disponível em: https://www.publico.pt/culturaipsilon/noticia/dulce-1708071. Acesso em 6 fev. 2016.

LOURENÇO, Eduardo. O labirinto da saudade. Psicanálise mítica do destino português. 2.ed. Lisboa: Dom Quixote, 1982.

LUGARINHO, Mário. "Masculinidade e colonialismo: em direção ao 'homem novo' (subsídios para os estudos de gênero e para os estudos pós-coloniais no contexto da língua portuguesa)". Abril - Revista do Núcleo de Estudos de Literatura Portuguesa e Africana da UFF, Niterói-RJ, v. 5, n. 10, p. 15-38, abr.2013.

MORAES, Anita Martins de. "Resenha a Caderno de memórias coloniais, de Isabela Figueiredo". 8 out. 2011. Disponível em http://www. buala.org/pt/a-ler/resenha-a-caderno-de-memorias-coloniais-de-isabela-figueiredo. Acesso em 14.fev.2016.

PINHO, Osmundo de Araújo. "O efeito do sexo: políticas de gênero, raça e miscigenação". Cadernos Pagu - UNICAMP, Campinas, v. 23, p. 89119, jul.-dez 2004.

PRATA, Ana Filipa, 2014. "O cronótopo do hotel e a formação da memória em o retorno, de Dulce Maria Cardoso". Navegações; Revista da PUCRS, Porto Alegre, v. 7, n.1, p. 69-76, jan-jun. 2014.

RIBEIRO, Margarida Calafate. "O fim da história de regressos e o retorno a África: leituras da literatura contemporânea portuguesa”. In: BRUGIONI, Elena et al. (orgs). Itinerâncias. Percursos e representações da pós-colonialidade. Braga: Centro de Estudos Humanísticos da Universidade do Minho, 2012. p.. 89-99.

RIBEIRO, Raquel. "Os retornados estão a abrir o baú". Publicado em 19 ago.2010. Disponível em http://www.buala.org/pt/a-ler/os-retornados-estao-a-abrir-o-bau. Acesso em 14.fev.2016.

SAID, Edward W. "Reflexões sobre o exílio". In: Reflexões sobre o exílio e outros ensaios. São Paulo: Companhia das Letras, 2003. p. 46-60.

SANTOS, Boaventura de Sousa. "Entre Prospero e Caliban: colonialismo, pós-colonialismo e inter-identidade". In: RAMALHO, Maria Irene e RIBEIRO, António Sousa (orgs.). Entre ser e estar; raízes, percursos e discursos da identidade. Porto: Afrontamento, 2002. p. 23-85. 
VIEGAS, Francisco José. “Caderno de memórias coloniais (Isabela Figueiredo)”. Publicado em 6 jan. 2010. Disponível em http://ler.blogs.sapo. pt/561570.html. Acesso em 14.02.2016.

\section{Recebido para publicação em 02/10/2015 \\ Aprovado em 27/02/2016}

\section{NOTAS}

*Doutora em Teoria Literária (PUCRS), com Pós-Doutorado na Universidade Nova de Lisboa e na UFF. Professora Associada da UFSC, onde se dedica ao ensino de Literatura Portuguesa e Literaturas Africanas de Língua Portuguesa, e desenvolve pesquisa nas áreas de estudos feministas e pós-coloniais.

1 Para discutir os efeitos da "densa e longa temporalidade do colonialismo português" (SANTOS, 2002, p. 29), Boaventura de Sousa Santos cita Carlos Fortuna: "quando Portugal se constituiu em autêntico poder colonial [fê-lo] num sentido duplo de colonizador a destempo. Colonizou quando os ventos da descolonização já começavam a fazer-se sentir por toda África, e fê-lo com uma arrogância só compreensível à luz de uma repentina consciência política de que era preciso recompensar a todo o custo o tempo e o projecto colonial perdidos. Não surpreende que, perante este tardo-colonialismo, também a descolonização portuguesa tenha sido tardia e os seus custos elevados. Teve que ser pago o preço de 13 anos de guerra colonial, gastar-se nela quase metade do orçamento nacional anual, endividar progressivamente o país, reforçar os elos de dependência externa, mobilizar 15 por cento dos cidadãos em idade militar. Enfim, teve que se empenhar uma nação e um regime numa causa historicamente perdida, se vista à luz das tendências seculares do sistema-mundo e da evolução do ciclo colonial africano." (FORTUNA, 1993, p. 41 apud SANTOS, 2002, p. 29).

2 Raquel Ribeiro cita, em seu artigo "Os retornados estão a abrir o baú” (2010), outra passagem esclarecedora de Eduardo Lourenço: "Mesmo na hora solar da nossa afirmação histórica, essa grandeza era, concretamente, uma ficção. Nós éramos grandes [...], mas éramos grandes longe, fora de nós, no Oriente de sonho ou num Ocidente impensado ainda." (LOURENÇO apud RIBEIRO, 2010)

3 Entre os escritores que abordaram diretamente o tema do retorno, nome incontornável é o de António Lobo Antunes, que principalmente em dois de seus romances, As naus e $O$ esplendor de Portugal, tratou de forma contundente as dificuldades vividas pelos retornados em Portugal. Acrescento também os romances Partes de África e Pedro e Paula, ambos de Helder Macedo, e O Tibete de África, de Margarida Paredes, que encenam os dramas dos retornados, ainda que não de forma central em suas narrativas.

4 Segundo Ribeiro, esses livros, juntamente com outros que os precederam, "representam a significativa parte da comunidade portuguesa que se imagina a partir de um discurso 'pós-luso-tropical' e que assim se subtrai a uma reflexão sobre a violência política, social e epistémica que foi o colonialismo". (RIBEIRO, 2012, p. 92)

5 Segundo Sheila Khan, o livro de Isabela Figueiredo foi uma 'pedrada no charco. "A maneira como ela entra no texto, ninguém quer ouvir aquilo. Tínhamos uma ideia muito pacífica e paradisíaca do colonialismo português em África”. (KHAN apud RIBEIRO, 2010).

6 No artigo intitulado “Os retornados estão a abrir o baú”, Raquel Ribeiro acrescenta ainda outros nomes à lista de autores que, numa perspectiva crítica e pós-colonial, abordam o tema do retorno em sua produção recente. António Mateus (Lobito, 2009; Lubango, Paris, Mavinga, 2010) e Manuel Acácio (A balada do Ultramar, 2009) são exemplos dessa abordagem.

7 Cf. VIEGAS,2010: "Isabela Figueiredo providencia socos no estômago, às vezes desnecessários, mas pressente-se a sua urgência, aquela espécie de queda para o abismo que leva a mexer em todas as feridas, as pessoais e as da rua, as da multidão de retornados que chegaram à Metrópole e começaram a viver perto da linha que delimita o nada e o tudo". 
9 Entrevista a Margarida Cardoso. Disponível em http://www.ulusofona.pt/lessons/margarida-cardoso. Acesso em 14 fev. 2016.

10 Cf. Margarida Cardoso (2012): "Natal 71 é o nome de um disco oferecido aos militares em guerra no Ultramar português nesse mesmo ano. Cancioneiro do Niassa é o nome que foi dado a uma cassete áudio, gravada clandestinamente por militares ao longo dos anos de guerra, em Moçambique. Era o tempo em que Portugal era um grande império colonial - pelo menos era o que eu lia nos livros da escola - e para que assim continuasse, o meu pai e grande parte da sua geração combateu nessa guerra, que durou treze anos. Hoje transportamos, em silêncio, essas memórias. Olho para trás e tento ver. Em casa do meu pai encontrei algumas fotografias, a cassete e o disco. A cassete é uma voz de revolta, o disco é uma peça de propaganda nacionalista. São memórias de uma ditadura fascista. Memórias de um país fechado do resto do mundo, pobre e ignorante, adormecido por uma propaganda melosa e primária que nos tentava esconder todos os conflitos, e que nos impedia de pensar e de reconhecer a natureza repressiva do regime em que vivíamos".

11 Refiro-me aqui à conhecida figura benjaminiana do anjo da História, metáfora construída pelo pensador alemão a partir do quadro de Paul Klee, em "Teses sobre o conceito de História" ( 1987).

12 Cf. SAID, Edward, 2003, p. 59: "A maioria das pessoas tem consciência de uma cultura, um cenário, um país; os exilados têm consciência de pelo menos dois desses aspectos, e essa pluralidade de visão dá origem a uma consciência de dimensões simultâneas, uma consciência que - para tomar emprestada uma palavra da música - é contrapontística”.

13 Cf. RIBEIRO, 2012, p. 94: "Mas quem é afinal um filho da ditadura, da Guerra Colonial ou dos retornados? Alguém para quem essas vivências são já uma representação, alguém que se constitui como o herdeiro simbólico de uma ferida aberta sobre a qual elabora uma narrativa - um testemunho possível, um "testemunho adoptivo", "subjectivo" na acepção de alguns teóricos (Hartman, 1991; Sarlo, 2007) - construído a partir de memórias de infância, fragmentos das narrativas familiares, compostas por discursos, fotografias, mapas, cartas, aerogramas e outros objetos de domínio privado e também por fragmentos retirados de narrativas públicas (Ribeiro, Ribeiro, Vecchi, 2010). [...] Neste quadro, há um conceito relativamente recente, o de pós-memória, que recoloca o amplo debate sobre a memória, o testemunho e a representação (Ribeiro, Ribeiro, Vecchi, 2010). E recoloca porque se funda sobre eles, mas também os interroga e os desestabiliza.” 